\title{
ANALISIS MUTU IKAN PATIN (Pangasius sp.) SALAI DENGAN PEMBERIAN KITOSAN DAN LAMA PENGASAPAN SEBAGAI RANCANGAN LKPD BIOLOGI SMA
}

\author{
Sri Wulandari ${ }^{1)}$, Elya Febrita ${ }^{2)}$, Anugrah Tifanny ${ }^{3)}$ \\ E-mail: anugrah.tifanny4876@student.unri.ac.id \\ ${ }^{12) 3)}$ Program Studi Pendidikan Biologi, FKIP Universitas Riau
}

\begin{abstract}
:
The aims to determine the effect of chitosan concentration and smoking time on the quality of smoked catfish (Pangasius sp.) and produce Student Worksheet design. This research was divided into two step, there is experimental step and the Student Worksheet design. At the experimental step, used a factorial Completely Randomized Design (CRD). Factor I is the concentration of chitosan, and factor II is duration of smoking time. This study consisted of 12 treatments with 3 replications so that there were 36 experimental units. Parameters observed were protein content, fat content, water content and organoleptic on appearance, scent, taste and texture. The results showed that the effect of chitosan concentration and smoking time had an effect on treated with $3 \%$ chitosan and 3 days of smoking showed the best results, with the total protein content was $35.89 \%$, fat content was $29.72 \%$ and water content was $15.27 \%$. Meanwhile, the organoleptic test results of smoked catfish on the aspects of appearance, scent, taste and texture, the best treatment was also found in smoked catfish with 3\% chitosan treatment and 3 days of smoking time. The results can be used as a student worksheet design on Food Additives material for class XI high school.
\end{abstract}

Keywords: Chitosan, Smoking Time, Pangasius sp, Student Worksheet

\section{PENDAHULUAN}

Ikan patin merupakan ikan yang banyak diminati di Indonesia, khususnya daerah Riau dan menjadi salah satu andalan dalam peningkatan produktivitas budidaya perikanan. Ikan patin termasuk bahan pangan yang bersifat perishable yaitu mudah mengalami pembusukan dan bisa berakibat pada penurunan nilai ekonomi hingga penolakan konsumen. Hal tersebut dikarenakan kadar air dalam ikan yang cukup tinggi sehingga memungkinkan cepat terjadinya kerusakan pada produk perikanan. Menurut Afrianto dan Liviawaty (1989), proses pembusukan ikan dapat disebabkan oleh aktivitas enzim yang terdapat di dalam tubuh ikan sendiri, aktivitas mikroorganisme, atau proses oksidasi pada lemak tubuh oleh oksigen dari udara. Untuk mengurangi kadar air dalam ikan dilakukan pengolahan ikan berupa pengawetan agar dapat meningkatkan mutu produk perikanan. Salah satu produk olahan ikan patin adalah ikan asap atau yang biasa disebut ikan salai.

Ikan patin salai merupakan produk awetan dengan memanfaatkan kombinasi perlakuan pengeringan dan pemberian senyawa kimia dari hasil pembakaran bahan bakar alami (Wibowo, 2000). Pengasapan sangat berpengaruh terhadap peningkatan umur penyimpanan produk perikanan. Umur penyimpanan ikan salai berkaitan dengan lama waktu pengasapan ikan. Semakin lama waktu pengasapan yang diberikan maka ikan yang dihasilkan akan semakin awet. Hal ini dikarenakan semakin lama ikan diasapi, maka semakin sedikit kandungan air dan lemak ikan tersebut.

Ikan patin bila diolah menjadi ikan salai (pengasapan ikan), disamping mempunyai daya simpan ikan lebih lama, pengolahan ikan dengan cara pengasapan ini selain umumnya disukai 
konsumen, dapat meningkatkan daya saing dan nilai tambah ikan patin itu sendiri mencapai 2 hingga 3 kali lipat dibanding harga ikan patin segar, namun mempunyai umur simpan yang relatif pendek. Husein dan Daeng (2018), mengatakan produk ikan asap mempunyai umur simpan yakni berkisar 4-8 hari, setelah hari ke 8 daging ikan asap tidak layak dikonsumsi lagi karena telah terjadi kerusakan produk. Kerusakan yang terjadi pada ikan asap adalah tumbuhnya jamur atau kapang sebab jamur bisa tumbuh pada makanan berkadar air rendah. Pertumbuhan jamur pada ikan asap dapat menimbulkan terjadinya perubahan seperti bau ikan asap menjadi tengik, terbentuknya spotspot putih di permukaan ikan dan perubahan tekstur daging. Untuk mempertahankan mutu ikan patin salai diperlukan suatu bahan tambahan pangan untuk mempertahankan umur simpannya. Salah satu bahan tambahan tersebut adalah dengan penambahan kitosan.

Kitosan digunakan sebagai edible film atau edible coating pada industri untuk meningkatkan kualitas dari bahan pangan, menjadi antimikroba untuk daya simpan bahan pangan, untuk pemurnian air, memberikan efek nutrisi bagi makanan dan lain-lain (Shahidi, 1999). Penggunaan kitosan diharapkan dapat meningkatkan mutu dan organoleptik ikan patin salai yang bertindak sebagai pengawet. Hal ini dikarenakan kitosan merupakan bahan alami yang direkomendasikan sebagai pengawet makanan karena tidak beracun dan aman bagi kesehatan juga lebih aman dibandingkan dengan senyawa kimia sintesis.

Aspek kualitas dari daging ikan patin salai diantaranya kadar protein, kadar lemak, kadar air dan nilai organoleptic dapat di intergrasikan menjadi rancangan rancangan bahan ajar dalam mata pelajaran biologi berupa rancangan bahan ajar dalam bentuk Lembar Kerja Peserta Didik (LKPD) pada konsep zat aditif makanan SMA Kelas XI.

\section{METODE PENELITIAN}

Penelitian dilakukan selama bulan Juli hingga September 2020 di Laboratorium Pendidikan Biologi Fakultas Keguruan dan Ilmu Pendidikan dan Laboratorium Teknologi Hasil Perikanan Fakultas Perikanan dan Kelautan Universitas Riau. Penelitian ini menggunakan rancangan acak lengkap (RAL) pola faktorial. Faktor I adalah konsentrasi kitosan (K) yang terdiri atas 4 taraf yaitu $\mathrm{K} 0=0$ gr bubuk kitosan, $\mathrm{K} 1=5$ gr bubuk kitosan, $\mathrm{K} 2=10$ gr bubuk kitosan, $\mathrm{K} 3=15$ gr bubuk kitosan. Faktor II yaitu lama waktu pengasapan (W), antara lain: $\mathrm{W} 1=1$ hari pengasapan, W2 $=2$ hari pengasapan, W3 = 3 hari pengasapan. Penelitian ini terdiri dari 12 perlakuan dengan 3 ulangan sehingga terdapat 36 unit rancangan percobaan. Parameter penelitian ini terdiri dari kadar protein, kadar lemak, kadar air dan uji organoleptik.

Tahap perancangan LKPD dilakukan melalui tahap analisis dan desain. Tahap analisis dilakukan dengan merekonstruksi silabus dan kompetensi dasar. Pada tahap design dilakukan dengan merancang perangkat pembelajaran meliputi silabus, RPP, dan LKPD.

\section{HASIL DAN PEMBAHASAN}

\section{Pengaruh Pemberian Kitosan Dan Lama Pengasapan Terhadap Mutu Ikan Patin Salai A. Sebelum Penyimpanan}

Sebelum penyimpanan, ikan yang telah diberi perlakuan konsentrasi kitosan $0 \%, 1 \%, 2 \%, 3 \%$ dan lama pengasapan 1, 2, 3 hari langsung dilakukan uji analisis proksimat terhadap mutu ikan patin salai yang terdiri dari kadar protein, kadar lemak, dan kadar air. Rata-rata kadar protein, kadar lemak dan kadar air ikan patin salai berdasarkan berbagai penambahan konsentrasi kitosan dan lama waktu pengasapan sebelum penyimpanan dapat dilihat pada Tabel 1 berikut ini. 
Tabel 1. Rata-rata kadar protein, kadar lemak dan kadar air (\%) pada ikan patin salai sebelum penyimpanan.

\begin{tabular}{cccc}
\hline \multirow{2}{*}{ Perlakuan } & \multicolumn{3}{c}{ Parameter } \\
\cline { 2 - 4 } & Kadar Protein (\%) & Kadar Lemak (\%) & Kadar Air (\%) \\
\hline W1K0 (1 hari, 0\%) & $19.24^{\mathrm{a}}$ & $29.27^{\mathrm{d}}$ & $36.26^{\mathrm{i}}$ \\
W1K1 (1 hari, 1\%) & $24.39^{\mathrm{c}}$ & $27.14^{\mathrm{c}}$ & $33.03^{\mathrm{h}}$ \\
W1K2 (1 hari, 2\%) & $28.07^{\mathrm{e}}$ & $24.96^{\mathrm{b}}$ & $26.11^{\mathrm{f}}$ \\
W1K3 (1 hari, 3\%) & $32.91^{\mathrm{fg}}$ & $23.32^{\mathrm{a}}$ & $24.83^{\mathrm{f}}$ \\
W2K0 (2 hari, 0\%) & $23.05^{\mathrm{b}}$ & $32.97^{\mathrm{e}}$ & $28.45^{\mathrm{g}}$ \\
W2K1 (2 hari, 1\%) & $27.05^{\mathrm{d}}$ & $29.10^{\mathrm{d}}$ & $24.34^{\mathrm{e}}$ \\
W2K2 (2 hari, 2\%) & $32.24^{\mathrm{f}}$ & $26.97^{\mathrm{c}}$ & $22.43^{\mathrm{e}}$ \\
W2K3 (2 hari, 3\%) & $39.52^{\mathrm{i}}$ & $25.21^{\mathrm{b}}$ & $18.43^{\mathrm{d}}$ \\
W3K0 (3 hari, 0\%) & $27.78^{\mathrm{de}}$ & $37.97^{\mathrm{g}}$ & $15.99^{\mathrm{c}}$ \\
W3K1 (3 hari, 1\%) & $33.20^{\mathrm{g}}$ & $35.92^{\mathrm{f}}$ & $13.93^{\mathrm{b}}$ \\
W3K2 (3 hari, 2\%) & $37.64^{\mathrm{h}}$ & $32.95^{\mathrm{e}}$ & $12.19^{\mathrm{b}}$ \\
W3K3 (3 hari, 3\%) & $41.63^{\mathrm{j}}$ & $32.71^{\mathrm{e}}$ & $9.31^{\mathrm{a}}$ \\
\hline
\end{tabular}

(W = lama hari pengasapan, $\mathrm{K}=$ konsentrasi kitosan)

Ket: Angka yang diikuti oleh huruf yang berbeda menunjukkan berbeda nyata pada uji DMRT taraf 5\%.

Pada tabel 1, kadar protein tertinggi terdapat pada ikan patin salai dengan perlakuan 3 hari pengasapan dengan konsentrasi kitosan 3\%. Sedangkan kadar protein terendah terdapat pada ikan dengan perlakuan 1 hari pengasapan dengan konsentrasi kitosan 0\%. Semakin tinggi konsentrasi larutan kitosan dan lama waktu pengasapan yang diberikan maka semakin tinggi kadar protein ikan patin salai.

Pemberian larutan kitosan dan lama waktu pengasapan juga berpengaruh nyata terhadap kadar lemak ikan patin salai. Pada ikan patin dengan perlakuan pengasapan 1 hari, 2 hari, dan 3 hari kadar lemak terendah terdapat pada kitosan dengan konsentrasi 3\%. Hal ini menunjukkan bahwa, semakin tinggi konsentrasi kitosan dan semakin lama waktu pengasapan yang diberikan maka kadar lemak semakin rendah.

Selain itu, konsentrasi larutan kitosan dan lama waktu pengasapan juga berpengaruh nyata terhadap kadar air ikan patin salai. Kadar air tertinggi terdapat pada perlakuan 1 hari pengasapan dan $0 \%$ konsentrasi larutan kitosan. Sedangkan kadar air terendah pada perlakuan 3 hari pengasapan dan 3\% konsentrasi larutan kitosan. Semakin tinggi konsentrasi larutan kitosan dan lamanya waktu pengasapan yang diberikan, maka makin rendah kadar air yang terdapat pada ikan patin salai.

\section{B. Setelah Penyimpanan}

Ikan patin salai yang telah disimpan, selanjutnya diuji analisis proksimat dengan lama waktu pengasapan 3 hari dengan konsentrasi 0\%-3\%, sedangkan produk ikan patin salai perlakuan 1 dan 2 hari pengasapan dengan konsentrasi kitosan 0\%-3\%, tidak dilakukan analisis lajutan. Pada produk ikan patin salai 1 dan 2 hari pengasapan, kenampakan produk ikan dapat dilihat pada gambar berikut ini:
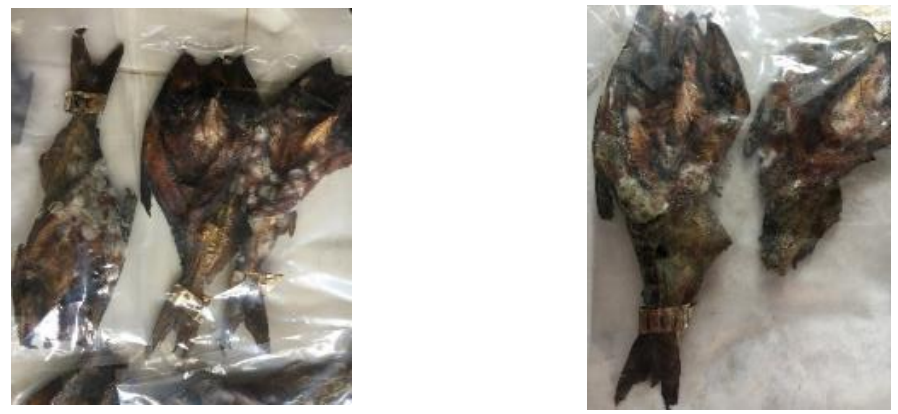

Gambar 1. Ikan patin (Pangasius sp) salai dengan perlakuan 1 dan 2 hari pengasapan. 
Produk ikan patin salai dengan perlakuan 1 dan 2 hari pengasapan sudah mengalami kerusakan. Kerusakan tersebut berupa terdapatnya spot-spot putih di permukaan ikan atau tumbuhnya jamur pada produk. Selain itu, produk juga sudah berbau tengik dan rasa daging ikan yang sudah getir. Ciri-ciri seperti ini menandakan bahwa ikan sudah tidak layak dikonsumsi dan mutu ikan juga sudah tidak baik.

Pada ikan patin salai dengan perlakuan pengasapan 3 hari tidak menunjukkan satupun ciriciri yang sama dengan ikan patin salai pengasapan 1 dan 2 hari. Ikan masih dalam kondisi bagus dan layak dikonsumsi. Adapun rata-rata kadar protein, kadar lemak dan kadar air ikan patin salai berdasarkan berbagai penambahan konsentrasi kitosan 0\%-3\% dan lama waktu pengasapan 3 hari setelah penyimpanan dapat dilihat pada tabel 2 berikut.

Tabel 2. Rata-rata kadar protein, kadar lemak dan kadar air (\%) pada ikan patin (Pangasius sp) salai setelah penyimpanan.

\begin{tabular}{cccc}
\hline Perlakuan & \multicolumn{3}{c}{ Parameter } \\
\cline { 2 - 4 } & Kadar Protein (\%) & Kadar Lemak (\%) & Kadar Air (\%) \\
\hline W3K0 (3 hari, 0\%) & $22.42^{\mathrm{a}}$ & $20.36^{\mathrm{a}}$ & $27.27^{\mathrm{d}}$ \\
W3K1 (3 hari, 1\%) & $26.10^{\mathrm{b}}$ & $23.46^{\mathrm{b}}$ & $20.04^{\mathrm{c}}$ \\
W3K2 (3 hari, 2\%) & $31.20^{\mathrm{c}}$ & $26.11^{\mathrm{c}}$ & $18.07^{\mathrm{b}}$ \\
W3K3 (3 hari, 3\%) & $35.89^{\mathrm{d}}$ & $29.72^{\mathrm{d}}$ & $15.27^{\mathrm{a}}$ \\
\hline
\end{tabular}

(W = lama hari pengasapan, $\mathrm{K}=$ konsentrasi kitosan)

Ket: Angka yang diikuti oleh huruf yang berbeda menunjukkan berbeda nyata pada uji DMRT taraf 5\%.

Ikan patin salai dengan lama waktu pengasapan 3 hari dan diberi berbagai konsentrasi larutan kitosan berpengaruh nyata terhadap kadar protein. Kadar protein ikan patin salai tertinggi terdapat pada ikan dengan perlakuan W3K3 Sedangkan kadar protein terendah terdapat pada ikan dengan perlakuan W3K0. Perbedaan jumlah rerata kadar protein pada ikan patin salai dikarenakan semakin tingginya pemberian konsentasi kitosan dapat menambah kandungan protein pada daging ikan karena banyak memiliki gugus $\mathrm{NH}_{3}{ }^{+}$dari kitosan yang dapat berikatan dengan gugus $\mathrm{NH}_{2}$ pada daging ikan sehingga dapat membentuk $\mathrm{NH}_{4}{ }^{+}$dan gugus lainnya dilepaskan untuk membentuk asam amino baru. Banyaknya gugus $\mathrm{NH}_{4}{ }^{+}$dapat menambah massa. Penambahan kitosan dapat menambah massa otot dan menghambat masuknya $\mathrm{H}_{2} \mathrm{O}$ dalam daging ikan. Sehingga semakin tinggi konsentrasi kitosan yang digunakan maka akan meminimalkan kerusakan protein akibat proses penyalaian dan bertambahnya kadar protein pada daging ikan patin. Hal ini sesuai menurut Wang et al. (2020) Penambahan kitosan pada ikan patin dapat meningkatkan protein karena kitosan memiliki gugus $\mathrm{NH}_{2}$ yang dapat berikatan langsung dengan $\mathrm{NH}_{3}{ }^{+}$pada daging ikan sehingga membentuk $\mathrm{NH}_{4}{ }^{+}$. Kitosan memiliki sifat afinitas atau daya mengikat yang luar biasa terhadap protein, hal ini disebabkan karena terjadinya akumulasi asam amino sehingga kadar protein meningkat.

Lama pengasapan juga berpengaruh terhadap kadar protein ikan salai. Hal ini dikarenakan semakin kering suatu bahan makanan maka semakin tinggi kadar proteinnya. Pemanasan dengan suhu tinggi akan menyebabkan kehilangan air yang lebih tinggi sehingga akan meningkatkan jumlah karbohidrat dan protein. Hal ini sesuai dengan pernyataan Winarno (2004) bahwa dengan berkurangnya kadar air maka akan meningkatkan kadar protein, dengan adanya pemanasan akan menyebabkan perubahan struktur protein atau biasa disebut denaturasi protein. Selama penyimpanan semua perlakuan mengalami penurunan nilai kadar protein, hal ini disebabkan oleh rusaknya molekul protein yang disebabkan oleh proses degradasi selama penyimpanan. Degradasi protein terjadi karena adanya pengaruh dari lingkungan penyimpanan, aktifitas mikroba, $\mathrm{pH}$ dan reaksi kimia enzimatis yang berlangsung selama penyimpanan.

Pada kadar lemak ikan patin salai, Pemberian konsentrasi kitosan 3\% dapat menyerap minyak atau menurunkan kadar lemak lebih tinggi karena kitosan 3\% dapat mengikat lemak dan melepaskan satu gugus lemak dari rantai lemak. Kitosan digolongkan sebagai turunan selulosa, 
karena struktur kitosan mirip dengan selulosa dengan gugus hidroksil yang digantikan dengan gugus amina sehingga dapat mengikat lemak. Menurut Wang et al., (2020) terjadinya penurunan lemak karena kitosan memiliki gugus $\left(\mathrm{CH}_{2}\right)_{12} \mathrm{CH}_{3}$ sehingga $\mathrm{N}_{3}$ kitosan dapat berikatan dengan $\mathrm{C}$ pada lemak dan menggantikan atom $\mathrm{H}$ dengan $\mathrm{N}$ pada rantai akhir dalam sistem lingkar pada lemak.

Penurunan kadar lemak pada ikan patin salai untuk ketiga perlakuan pemberian kitosan dikarenakan terjadinya proses oksidasi dari lemak akibat adanya kontak $\mathrm{O} 2$ dari udara dengan asam lemak yang akan mengakibatkan kerusakan lemak tersebut. Diduga kadar air yang tinggi pada produk ikan menyebabkan terjadinya reaksi hidrolisis sehingga menurunkan kadar lemak. Selama penyimpanan berlangsung, oksidasi tetap berjalan sesuai dengan permeabilitas kemasan terhadap oksigen dimana plastik yang digunakan untuk mengemas ikan salai ini adalah plastik jenis polyethylene yang tingkat ketahanannya terhadap oksigen rendah. Kelemahan dari penggunaan plastik mempunyai permeabilitas yang tinggi terhadap gas organik dan oksigen, maka masih mungkin bahan teroksidasi dan mengalami kerusakan. Hal ini sesuai dengan pernyataan Killay et al., (2015), bahwa kenaikan kadar air diikuti dengan penurunan kadar lemak. Penurunan kadar lemak selama penyimpanan juga disebabkan oleh proses hidrolisis sehingga mengakibatkan berubahnya asam lemak menjadi asam lemak bebas dan gliserol, dimana proses hidrolisa akan mengakibatkan kerusakan lemak karena terdapatnya jumlah air dalam lemak tersebut.

Pemberian berbagai konsentrasi larutan kitosan pada ikan patin salai dengan pengasapan selama 3 hari juga berpengaruh nyata terhadap kadar air ikan. Konsentrasi kitosan 3\% memiliki kadar air yang paling rendah karena gugus molekul $\mathrm{NH}_{4}{ }^{+}$lebih tinggi sehingga berkemampuan dalam melindungi lapisan membran sel dari kelembapan dan mengikat air pada daging ikan selama penyimpanan. Hal ini sesuai dengan pernyataan Febriandi (2015) bahwa kitosan dapat membentuk lapisan yang bersifat semipermeabel pada permukaan sel tubuh ikan salai sehingga bisa dilewati oleh aktivitas $\mathrm{O}_{2}, \mathrm{CO}_{2}$ dan mengikat gugus $\mathrm{H}$ pada molekul $\mathrm{H}_{2} \mathrm{O}$ sehingga tidak terjadinya kelembapan.

Perubahan kadar air pada proses pengasapan diakibatkan karena panas dan penarikan air dari jaringan tubuh ikan oleh penyerapan berbagai senyawa kimia dari asap, selain itu suhu dan lama pemanasan juga mempengaruhi nilai kadar air ikan salai. Pada bahan pangan yang dipanaskan, total air/cairan yang keluar dari produk, akan semakin banyak dengan semakin meningkatnya temperatur dan lama proses pengasapan. Peningkatan kehilangan cairan akan semakin besar pada suhu pemanasan di atas $100^{\circ} \mathrm{C}$ dan peningkatan waktu lebih dari 45 menit. Hal ini sesuai dengan yang terjadi pada semua perlakuan dengan lama pengasapan yang berbeda. Semakin lama waktu pengasapan maka kadar air yang terkandung dalam daging ikan semakin berkurang.

Selama penyimpanan, ikan salai mengalami peningkatan kadar air. Diduga peningkatan kadar air ini dipengaruhi oleh kelembaban ruang penyimpanan, kelembaban ruangan yang tinggi mengakibatkan produk menyerap air dari lingkungan. Kelembaban udara pada suhu ruang mempengaruhi peningkatan kadar air yang dihasilkan, semakin tinggi nilai kelembaban udara maka semakin banyak kandungan uap airnya sehingga kadar air produk meningkat. Kadar air yang tinggi dapat menyebabkan produk lebih mudah mengalami kerusakan, karena adanya mikroorganisme perusak yang memanfaatkan banyaknya air yang terkandung dalam produk untuk pertumbuhannya. Tingginya kadar air mengakibatkan mudahnya bakteri dan jamur untuk berkembang biak, sehingga akan terjadi perubahan pada bahan pangan.

\section{Uji Organoleptik Ikan Patin Salai}

Pengujian organoleptik bertujuan untuk mengetahui tingkat kesukaan dan nilai dari produk olahan ikan patin salai dari aspek kenampakan, aroma, rasa dan tekstur dari penambahan berbagai konsentrasi larutan kitosan dan lama waktu pengasapan yang merupakan penerimaan umum dari responden. Adapun rata-rata hasil uji organoleptik ikan patin salai terhadap aspek kenampakan, aroma, rasa dan tekstur dapat dilihat tabel 3 berikut. 
Tabel 3. Hasil uji organoleptik aspek kenampakan, aroma, rasa dan tekstur terhadap ikan patin (Pangasius sp) salai dengan penambahan kitosan dan lama pengasapan

\begin{tabular}{ccccc}
\hline \multirow{2}{*}{ Perlakuan } & \multicolumn{4}{c}{ Skor/Nilai } \\
\cline { 2 - 5 } & Kenampakan & Aroma & Rasa & Tekstur \\
\hline W1K0 & 6,2 & 5,6 & 5 & 4,2 \\
W1K1 & 6,2 & 6,6 & 5,8 & 5,2 \\
W1K2 & 5,6 & 5,8 & 4,8 & 4,4 \\
W1K3 & 7,2 & 6,8 & 6,2 & 5 \\
W2K0 & 6,8 & 6,8 & 6,6 & 6,4 \\
W2K1 & 7,4 & 6,8 & 6,6 & 6,4 \\
W2K2 & 7,2 & 7,2 & 6,4 & 6,4 \\
W2K3 & 6,4 & 6,2 & 5,2 & 5,8 \\
W3K0 & 8,2 & 8,6 & 8,2 & 8,4 \\
W3K1 & 8,4 & 8,4 & 7,8 & 8 \\
W3K2 & 8,6 & 8,8 & 8,2 & 8,4 \\
W3K3 & 9 & 9 & 8,4 & 9 \\
\hline
\end{tabular}

a. Organoleptik Kenampakan

Kenampakan ikan patin salai yang terbaik yakni pada perlakuan pengasapan 3 hari dengan konsentrasi kitosan $1 \%, 2 \%$, dan 3\%. Hal ini dikarenakan hasil rata-rata uji organoleptik pada perlakuan tersebut bernilai $>7$ (sesuai SNI 2013) dengan deskripsi produk yaitu utuh, warna mengkilap spesifik produk.

Warna ikan asap yang diterima untuk kenampakan ikan asap ialah warna kuning keemasan sampai coklat gelap. Warna kuning keemasan dan dapat membangkitkan selera konsumen untuk menikmatinya. Semakin tinggi konsentrasi asap yang diberikan maka warna ikan pun akan semakin gelap atau kecokelatan. Karakteristik warna kuning keemasan sampai coklat gelap disebabkan oleh senyawa karbonil. Senyawa-senyawa karbonil dalam asap memiliki peranan pada pewarnaan. Jenis senyawa karbonil yang terdapat dalam asap antara lain adalah vanilin, siringaldehid, formaldehid, glikoaldehid dan aseton. Hal ini sesuai dengan pendapat menurut Ruiter (1979), bahwa karbonil berfungsi sebagai pembentuk warna pada ikan asap. Karbonil mempunyai efek terbesar pada terjadinya pebentukan warna coklat pada produk asapan. Pencoklatan terjadi dari reaksi Mailard, yaitu senyawa karbonil dari asap bereaksi dengan asam amino dari protein daging ikan. Warna yang terbentuk berkorelasi dengan suhu, kelembaban, kandungan protein, sumber serta waktu pengasapan.

Pemberian kitosan pada ikan patin salai tidak memberikan perubahan pada kenampakan produk ikan tersebut karena kitosan berperan melindungi permukaan ikan patin asap dan juga memiliki warna transparan sehingga tidak mempengaruhi kenampakan dari ikan patin salai.

\section{b. Organoleptik Aroma}

Aroma roma terbaik yang diterima responden yakni pada ikan dengan perlakuan pengasapan 3 hari, dengan nilai rata - rata >7 (sesuai SNI 2013). Dengan deskripsi aroma yakni spesifik ikan salai kuat. Aroma asap pada ikan salai yang terbentuk sebagian besar dipengaruhi oleh adanya senyawa fenol (siringol) dan karbonil serta sebagian kecil juga dipengaruhi oleh asam. Karakteristik bau khas ikan asap disebabkan oleh senyawa fenol yang ada didalam asap. Fenol dalam hubungannya dengan sifat sensoris mempunyai bau tajam menyengat. Meskipun senyawa fenol memegang peranan penting dalam flavour asap, namun diperlukan senyawa lain seperti karbonil sehingga karakteristik aroma asap dapat muncul.

Suhu pengasapan dan teknik pengasapan juga menghasilkan intensitas bau dan rasa asap yang bervariasi. Semakin tinggi suhu pengasapan maka akan meningkatkan deposit komponen asap. Menurut Wibowo (2000) standar mutu ikan asap yang berkualitas tinggi yaitu aroma spesifik ikan 
asap, tanpa bau tengik, masam dan busuk. Sehingga perlakuan pengasapan 1 dan 2 hari kurang diterima responden karena kurangnya aroma spesifik ikan asap.

Pemberian kitosan pada ikan patin salai tidak mempengaruhi aroma dari ikan patin salai. Menurut Febriandi (2015), kitosan berwarna putih kekuningan dan tidak berbau dan mudah dibentuk menjadi larutan, gel, pasta, membran dan serat yang bermanfaat dalam aplikasinya. Larutan kitosan yang diberikan bertujuan sebagai edible coating yang mampu melindungi dan melapisi ikan patin asap sehingga dapat mempertahankan aroma asli dan menjadi penghalang masuknya mikroba pembusuk.

\section{c. Organoleptik Rasa}

Responden lebih menyukai ikan salai dengan perlakuan pengasapan 3 hari. Nilai rata - rata hasil uji organoleptik pada ikan pengasapan 3 hari bernilai $>7$ (sesuai SNI 2013) dengan deskripsi rasa yakni spesifik ikan salai kuat. Kriteria mutu organoleptik yang baik untuk rasa ikan asap adalah enak, rasa asap lembut sampai tajam tanpa rasa getir atau pahit dan tidak berasa tengik.

Komponen-komponen fenol dari asap memiliki peranan penting dalam meresapkan citarasa. Senyawa fenol dalam asap merupakan hasil pirolisa dari selulosa dan lignin. Pembakaran kayu keras yang mengandung selulosa dan lignin akan menghasilkan fenol yang berperan dalam memberi citarasa.

Terjadinya perbedaan rasa antara ikan salai pengasapan 3 hari dengan 1 dan 2 hari pengasapan dapat disebabkan karena kurangnya lama waktu pengasapan. Perbedaan rasa ini berhubungan dengan terjadinya penguraian protein dan lemak melalui proses kimiawi yang terjadi akibat reaksi enzimatik, aktifitas mikroba dan peningkatan kadar air pada ikan patin salai. Pemberian kitosan tidak mempengaruhi rasa dari daging ikan patin salai, karena kitosan tidak berwarna, tidak berbau dan juga tidak memiliki rasa.

\section{d. Organoleptik Tekstur}

Responden lebih menyukai tekstur ikan dengan perlakuan pengasapan 3 hari dengan pengasapan 3 hari memiliki tekstur padat, kompak, dan antar jaringan sangat erat. Nilai rata - rata hasil uji organoleptik pada ikan salai dengan pengasapan 3 hari yakni >7 (sesuai SNI 2013). Ikan Pengasapan 3 hari membuat ikan menjadi sangat kering. Standar mutu ikan asap yang berkualitas tinggi yaitu daging ikan asap kompak, padat, cukup kering, tidak berair/berlandir, dan tidak terlihat adanya bakteri maupun kapang.

Selama pengasapan berlangsung terjadi fluktuasi suhu yang tinggi, sehingga menyebabkan kadar airnya berkurang dan menghasilkan tekstur menjadi lebih keras, sebaliknya bila kadar air tinggi menyebabkan tekstur menjadi lebih lunak. Menurut Isamu et al. (2012) semakin tinggi kadar air ikan asap, maka nilai teksturnya menjadi rendah, begitupun sebaliknya.

Pemberian kitosan dapat berpengaruh terhadap organoleptik ikan salai dari aspek tektur. Semakin tinggi pemberian konsentasi kitosan dapat menambah kandungan protein pada daging ikan.

\section{Potensi Perancangan Bahan Ajar LKPD dari Hasil Penelitian.}

Hasil penelitian dapat digunakan sebagai salah satu rancangan Lembar Kerja Peserta Didik (LKPD) pada pembelajaran biologi di SMA kelas XI pada KD 3.7

Perancangan LKPD terdiri dari 2 tahap yaitu, tahap analisis dan tahap desain.

a. Tahap Analisis (Analyze)

Dilakukan analisis kompetensi dasar yang sesuai dengan hasil penelitian yaitu KD 3.7., analisis silabus. Pada KD 3.7 terdiri atas 4 pertemuan/ materi yang dikembangkan terdapat pada pertemuan ke-2 materi Zat Aditif Makanan. 
b. Tahap Desain

Rancangan lembar kerja peserta didik yang akan dirancang berbasis pendekatan saintifik yang menekankan aktivitas siswa. LKPD yang dirancang adalah sebagai berikut.
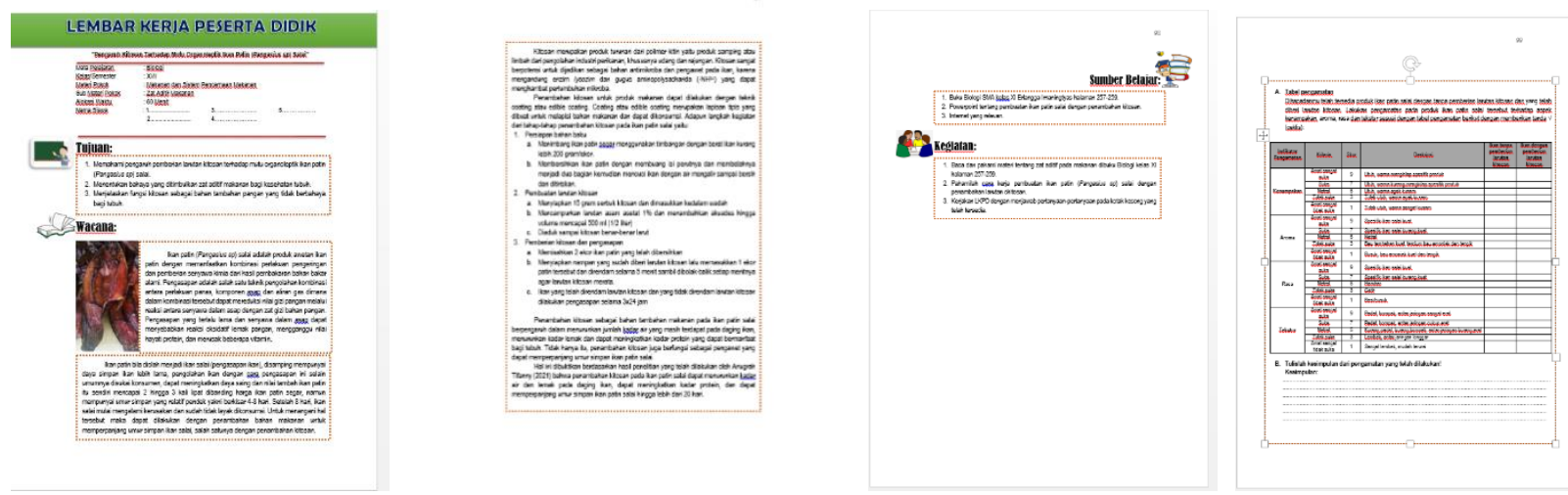

Gambar 2. Contoh Rancangan LKPD

\section{KESIMPULAN}

Penambahan konsentrasi kitosan dan lama pengasapan berpengaruh nyata terhadap mutu ikan patin (Pangasius sp) salai. Perlakuan yang terbaik terdapat pada ikan patin salai dengan konsentrasi kitosan 3\% dan lama waktu pengasapan 3 hari. Hasil penelitian ini dapat digunakan sebagai rancangan LKPD KD 3.7 pada materi Zat Aditif Makanan sebagai pengayaan pada mata pelajaran Biologi SMA kelas XI. Data hasil penelitian disarankan dilakukan pengujin secara mikrobiologi dan biomolekuler untuk mendapatkan data yang lebih akurat.

\section{DAFTAR PUSTAKA}

Afrianto, E dan Liviawaty, E. 1989. Pengawetan dan Pengolahan Ikan. Yogyakarta: Kanisius.

Febriandi, Sari, N. I dan Sukmiwati, M. 2015. "Pengaruh Perbedaan Cara Pelapisan Kitosan Terhadap Mutu Ikan Patin (Pangasius hypophthalmus) Asap Selama Penyimpanan Suhu Kamar". JOM

Husein, Azis dan Daeng, RA. 2018. "Pengaruh Lama Penyimpanan Terhadap Mutu Ikan Cakalang Asap (Katsuwonus pelamis)". Jurnal Agribisnis Perikanan, 11 (2), 59-64.

Isamu, K.T., Hari P. dan Sudarminto S. Y. 2012. "Karakteristik Fisik, Kimia dan Organoleptik Ikan Cakalang (Katsuwonus pelamis) Asap di Kendari”. Jurnal Teknologi Pertanian, 13 (2), 105110 .

Killay, A., Taslim, N.A., As'ad, S., dan Mahendratta, M. 2015. "Chitosan as Antimicrobial Agent and Fatty Acid Absorber in Smoked Skipjack Tuna Processes Using Coconut Shell”. American Journal Life of Sciences, 3(2), 93-99.

Ruiter, A. 1979. Color of Smoked Foods. Fodda Technol, 33 (5), 54-63.

Shahidi, F., Arachchi, J.K.V., dan Jeon Y-J. 1999. "Food Applications of Chitin and Chitosan". Trends in Food Science \& Technology, 10(2000), 37-51.

Wang, W., Xue, C., \& Mao, X. (2020). "Chitosan: Structural modification, biological activity and application". International Journal of Biological Macromolecules. 164, 4532-4546.

Wibowo, S. 2000. Industri Pengasapan Ikan. Jakarta: Penebar Swadaya.

Winarno FG. 2004. Kimia Pangan dan Gizi. Jakarta: PT Gramedia Pustaka Utama. 